\title{
A new genus and species of Sternaspidae (Annelida: Polychaeta) from the deep eastern Atlantic
}

\author{
Dieter FIEGE ${ }^{1, *}$ \& Ruth BARNICH ${ }^{2}$ \\ ${ }^{1}$ Forschungsinstitut und Naturmuseum Senckenberg Frankfurt, \\ Sektion Marine Evertebraten II, D-60325 Frankfurt am Main, Germany. \\ ${ }^{2}$ Thomson Environmental Consultants, Compass House, Surrey Research Park, \\ Guildford, GU2 7AG, United Kingdom. \\ ${ }^{*}$ Corresponding author: Dieter.Fiege@senckenberg.de \\ 2Email: Ruth.Barnich@thomsonec.com \\ ${ }^{1}$ urn:1sid:zoobank.org:author:80EC529E-71F4-4EB1-B22E-8861128AE8D6 \\ ${ }^{2}$ urn:1sid:zoobank.org:author:F1E3AEB7-0C77-41BB-8A6C-F8B429F17DA1
}

\begin{abstract}
Based on specimens recently collected in sediments from $2700 \mathrm{~m}$ depth off Mauritania (Northwest Africa; type locality) and from 2700-4400 m depth off Angola (Southwest Africa), a new genus and species, Mauretanaspis longichaeta gen. et spec. nov., is described. The new genus and species are characterized by a unique combination of characters: ventro-caudal shield covered by firmly adhering sediment, lateral margins strongly bent and merging into integument; introvert hooks tapering; eight pre-shield segments; absence of peg chaetae; exceptionally long posteriormost lateral chaetae equaling body length; posterior shield chaetae equaling shield length. A comparative table of characters for all currently recognised sternaspid genera and a key to all species with ventro-caudal shield covered by firmly adhering sediment are provided.
\end{abstract}

Keywords. Mauretanaspis longichaeta gen. et spec. nov., taxonomy, deep sea, Atlantic.

Fiege D. \& Barnich R. 2020. A new genus and species of Sternaspidae (Annelida: Polychaeta) from the deep eastern Atlantic. European Journal of Taxonomy 699: 1-13. https://doi.org/10.5852/ejt.2020.699

\section{Introduction}

Sternaspidae Carus, 1863 represents an enigmatic polychaete taxon characterized by the presence of a unique bilaterally symmetrical ventro-caudal shield. The taxonomy of Sternaspidae has received specific attention during recent years following the first revision of the group by Sendall \& SalazarVallejo (2013). Their morphological study resulted in the distinction of three genera (Sternaspis Otto, 1821, Caulleryaspis Sendall \& Salazar-Vallejo, 2013 and Petersenaspis Sendall \& Salazar-Vallejo, 2013) and a rapid increase of the number of species from 13 to 44, including the species described herein (Fiege 2016, 2019). With Sternaspis monroi Salazar-Vallejo, 2014, recently synoymized with S. sendalli Salazar-Vallejo, 2014 (Drennan et al. 2019), the actual number of species comes to 43. 
Table 1. Deep-water Sternaspidae known to date.

\begin{tabular}{lcc}
\hline Species & Distribution & Depth (m) \\
\hline Caulleryaspis fauchaldi Salazar-Vallejo \& Buzhinskaja, 2013 & NE Pacific, Oregon to Southern California & $1387-2800$ \\
Caulleryaspis gudmundssoni Sendall \& Salazar-Vallejo, 2013 & N Atlantic, Iceland & $452-1207$ \\
Caulleryaspis nuda Salazar-Vallejo \& Buzhinskaja, 2013 & NE Pacific, off Oregon & 2519 \\
Mauretanaspis longichaeta gen. et spec. nov. & NE and SE Atlantic, off Mauritania and Angola & $2700-4400$ \\
Sternaspis annenkovae Salazar-Vallejo \& Buzhinskaja, 2013 & NW Pacific, east of northern Kurile Island & $3980-4070$ \\
Sternaspis maior Chamberlin, 1919 & E Pacific, Central Gulf of California & $180-1143$ \\
Sternaspis maureri Salazar-Vallejo \& Buzhinskaja, 2013 & E and SW Pacific & $795-6489$ \\
Sternaspis princeps Selenka, 1885 & SW Pacific, New Zealand & 1274 \\
Sternaspis rietschi Caullery, 1944 & Arafura Sea, off Wokam Island & 1788 \\
Sternaspis sendalli Salazar-Vallejo, 2014 & Southern Ocean and Antarctic Peninsula & $200-1500$ \\
Sternaspis uschakovi Salazar-Vallejo \& Buzhinskaja, 2013 & N Pacific, Okhotsk Sea, California, Gulf of California & $592-2548$ \\
Sternaspis williamsae Salazar-Vallejo \& Buzhinskaja, 2013 & NE Pacific, Oregon to California & $1000-2800$ \\
\hline
\end{tabular}

Twelve of these are known to occur in deep waters (Table 1). Our present knowledge of the morphology, anatomy, biology and phylogeny of the group was summarized by Fiege $(2016,2019)$. A recent study by Drennan et al. (2019) investigated the phylogenetic relationships using molecular markers both within Sternaspidae as well as their position among the Polychaeta as a major taxon. Their molecular data of three genes (16S, 18S and CO1) places Sternaspidae next to Scalibregmatidae Malmgren, 1867 and these two families as a sistergroup of Cirratuliformia Fauchald, 1977 while other phylogenetic analyses using a higher number of genes paired Sternaspidae with Fauveliopsidae Hartman, 1971 (e.g., Rousset et al. 2007; for details see Fiege 2019 and Drennan et al. 2019). The latter authors also revealed a genetic connectivity among some species of Sternaspis across the Pacific. These molecular results also cast some doubt on the significance of the shield morphology for species distinction.

Below, we present a morphological description of a new genus and species, Mauretanaspis longichaeta gen. et spec. nov., recently collected in sediments from $2700 \mathrm{~m}$ depth off Mauritania (Northwest Africa) and from 2700-4400 m off Angola (Southwest Africa). Unfortunately, the material was not suitably preserved for a molecular analysis, but the unique combination of morphological characters allows a clear distinction from other sternaspid genera and species described to date. As mentioned by Drennan et al. (2019), the genera Sternaspis and Caulleryaspis are in need of revision, but we believe that the characters observed in our specimens are sufficient to establish a new genus and species.

The diagnostic characters of all sternaspid genera described so far, including the new genus established herein, are summarized in Table 2 and a key to all sternaspid species with a ventro-caudal shield covered by firmly adhering sediment is provided below.

\section{Material and methods}

The specimens were collected in deep-sea mud in a depth of about $2700 \mathrm{~m}$ during a benthic survey to the Block C9 area off Mauritania and in depths between about 2700-4400 m off Angola. Sampling was carried out in 2018 by the French environmental consultancy CREOCEAN on behalf of TOTAL. Specimens were sampled using a $0.25 \mathrm{~m}^{2}$ box core (Grey O'Hara), sieved on a semi-automatic table, fixed in $4 \%$ formalin in seawater and later transferred to $70 \%$ ethanol for preservation. Morphological studies were carried out using a Leica MZ8 and Leica M 125C stereo microsope. Photographs were taken with a Canon EOS 5D Mark II camera equipped with a $65 \mathrm{~mm}$ MP-E lens and a DMC 4500 Leica camera attached to the stereo microsope. Measurements were taken using an ocular micrometer. Counting of segments starts with chaetiger 1, i.e., pro- and peristomium are not included.The holotype is deposited at 
FIEGE D. \& BARNICH R., A new genus and species of Sternaspidae from the deep eastern Atlantic

Table 2. Distinctive characters of sternaspid genera (modified after Salazar-Vallejo 2017).

\begin{tabular}{lccc}
\hline Characters/Genera & $\begin{array}{c}\text { Sternaspis } \\
\text { Otto, 1821 }\end{array}$ & $\begin{array}{c}\text { Caulleryaspis } \\
\text { Sendall \& Salazar-Vallejo, 2013 }\end{array}$ & $\begin{array}{c}\text { Petersenaspis } \\
\text { Sendall \& Salazar-Vallejo, 2013 }\end{array}$ \\
\hline $\begin{array}{l}\text { Introvert hooks } \\
\text { No. pre-shield segments }\end{array}$ & Tapering & Tapering & Subdistally expanded (spatulate) \\
Shield structure & 7 & 7 & Tapering \\
& With ribs and/or & With or without faint ribs or & With faint ribs, without concen- \\
tric lines & Indistinct \\
Sediment firmly adhered to & concentric lines & concentric lines & Absent \\
shield & Absent & Present or absent & Present \\
Peg chaetae & Present & Present or indistinct & Absent \\
\hline
\end{tabular}

the Muséum national d'histoire naturelle, Paris (MNHN) and the paratype at the Senckenberg Museum Frankfurt (SMF). Additional material is deposited at the Senckenberg Museum Frankfurt, Muséum national d'histoire naturelle, Paris, Museo Nacional de Ciencias Naturales, Madrid (MNCN) and the Research Collection of the Department of Biology of the University of Aveiro, Marine Invertebrates (COBI at DBUA) as indicated under 'Material examined' below.

\section{Results}

\section{Taxonomy}

Phylum Annelida Lamarck, 1809

Class Polychaeta Grube, 1850

Family Sternaspidae Carus, 1863

Mauretanaspis gen. nov.

urn:1sid:zoobank.org:act:1FC8F8ED-C7A3-4EC9-AB69-6A0147632D23

Table 2

\section{Type species}

Mauretanaspis longichaeta gen. et spec. nov. designated herein.

\section{Diagnosis}

Sternaspids with introvert hooks tapering. Eight segments between gonopodial lobes and shield (i.e., preshield region). Ventro-caudal shield densely covered with firmly adhering fine sediment, which cannot be brushed off. Due to sediment cover no shield structures like ribs or concentric rings visible except median suture. Shield with lateral margins strongly bent towards dorsal side, merging into integument. Peg chaetae absent.

\section{Etymology}

The genus name is a combination of the Latin name for the type locality off the Northwest African state Mauritania (i.e., Mauretania, Lat.) and the Greek word 'aspis' (= 'shield'); gender: feminine.

\section{Remarks}

Mauretanaspis gen. nov. differs in the combination of characters from the other genera of Sternaspidae. The shield is completely and firmly covered by sediment, as in several species of Caulleryaspis, but it has eight pre-shield segments; peg chaetae (i.e., a dense group of short chaetae covered by a common sheath) are absent, while Caulleryaspis has seven pre-shield segments and peg chaetae are present. In Caulleryaspis nuda peg chaetae are absent, but according to Drennan et al. (2019) this species possibly belongs to the genus Sternaspis (see 'Discussion'). Petersenaspis has eight pre-shield segments and 
peg chaetae are absent, as in Mauretanaspis gen. nov., but the shield is not covered by sediment and the introvert hooks are subdistally expanded or spatulate while hooks in Mauretanaspis gen. nov. are tapering (Table 2).

Mauretanaspis longichaeta gen. et spec. nov. urn:1sid:zoobank.org:act:AA378791-074B-4349-B2E2-235FD632E35C

Figs $1-4$, Table 1

\section{Etymology}

The species epithet is a combination of the Latin 'longus' (= 'long') and the Greek 'chaeta' (= 'bristle') characterizing the striking length of the posteriormost lateral chaetae of the ventro-caudal shield.

\section{Material examined}

\section{Holotype}

NORTHEAST ATLANTIC - Off Mauritania 11 complete specimen (body slightly contracted, introvert fully everted, length $5.0 \mathrm{~mm}$, width $1.6 \mathrm{~mm}$, abdomen length $3.0 \mathrm{~mm}$, left shield plate length $1.2 \mathrm{~mm}$,

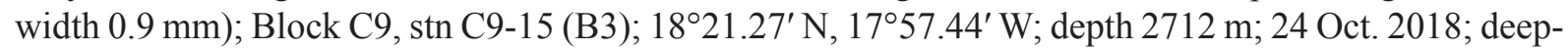
sea mud, box core; MNHN-IA-TYPE 2005.

\section{Paratype}

NORTHEAST ATLANTIC - Off Mauritania 1 complete specimen (introvert partly retracted, length $3.5 \mathrm{~mm}$, width $1.8 \mathrm{~mm}$, abdomen length $1.0 \mathrm{~mm}$, left shield plate length $1.2 \mathrm{~mm}$, width $1.2 \mathrm{~mm}$ ); Block C9, stn C9-15 (B1); 18 $21.27^{\prime} \mathrm{N}, 17^{\circ} 57.44^{\prime} \mathrm{W}$; depth $2712 \mathrm{~m}$; 24 Oct. 2018; deep-sea mud, box core; SMF 27777.

\section{Other material}

NORTHEAST ATLANTIC - Off Mauritania 1 spec. (bad condition, anterior end retracted, length n.d., width $2.6 \mathrm{~mm}$, abdomen length $3.7 \mathrm{~mm}$, left shield plate length $1.6 \mathrm{~mm}$, width $1.0 \mathrm{~mm}$ ); Block C9, stn C9-20 (B1); $18^{\circ} 26.91^{\prime} \mathrm{N}, 17^{\circ} 59.25^{\prime} \mathrm{W}$; depth 2714 m; 27 Oct. 2018; deep-sea mud, box core; SMF 27776.

SOUTHEAST ATLANTIC - Off Angola 1 spec. (juvenile with capillary chaetae in pre-shield segments, without gonopodial lobes, anterior end missing, length n.d., width $0.35 \mathrm{~mm}$ ); stn S48-03A; $6^{\circ} 53.107^{\prime} \mathrm{S}$, 10³0.762' E; depth 2935 m; 7 Sep. 2018; box core; MNHN-IA-PNT $120 \cdot 1$ spec. (juvenile, anterior end damaged, length n.d., width $0.65 \mathrm{~mm}$, left shield plate length $0.5 \mathrm{~mm}$ ); stn S48-08A; 6 $6^{\circ} 59.047^{\prime} \mathrm{S}$, 10³6.748' E; depth 2736 m; 9 Sep. 2018; box core; SMF 28061 - 1 spec. (gonopodial lobes present, length $3.2 \mathrm{~mm}$, width $1.1 \mathrm{~mm}$, left shield plate length $1.1 \mathrm{~mm}$ ); stn S48-09C; $7^{\circ} 4.931^{\prime} \mathrm{S}, 10^{\circ} 13.003^{\prime} \mathrm{E}$; depth 4373 m; 14 Sep. 2018; box core; SMF 28062 - 1 spec. (juvenile, body wall translucent, with chaetae in some abdominal segments, without gonopodial lobes, length $2.5 \mathrm{~mm}$, width $0.9 \mathrm{~mm}$ ); stn S48-14C; $7^{\circ} 10.998^{\prime}$ S, $10^{\circ} 13.064^{\prime}$ E; depth 4363 m; 14 Sep. 2018; box core; MNCN 16.01/18762 • 1 spec. (strongly bent and wrinkled, gonopodial lobes not seen, posteriormost lateral chaetae ca $4 \times$ length of body, length n.d., width n.d., left shield plate length $1.0 \mathrm{~mm}$ ); stn S48-23A; $7^{\circ} 23.159^{\prime} \mathrm{S}$, $10^{\circ} 24.921^{\prime}$ E; depth 4375 m; 15 Sep. 2018; box core; MNCN 16.01/18763 1 spec. (juvenile, body wall translucent, anterior end missing); stn S48-23B; $7^{\circ} 23.159^{\prime} \mathrm{S}, 10^{\circ} 24.921^{\prime} \mathrm{E}$; depth $4375 \mathrm{~m}$; 15 Sep. 2018; box core; DBUA0002349.01 - 1 spec. (anterior end retracted, gonopodial lobes retracted but visible, length n.d., width n.d., left shield plate length $1.0 \mathrm{~mm}$ ); stn S48-26C; $6^{\circ} 58.715^{\prime} \mathrm{S}, 10^{\circ} 17.741^{\prime} \mathrm{E}$; depth 4191 m; 10 Sep. 2018; box core; DBUA0002349.02. 


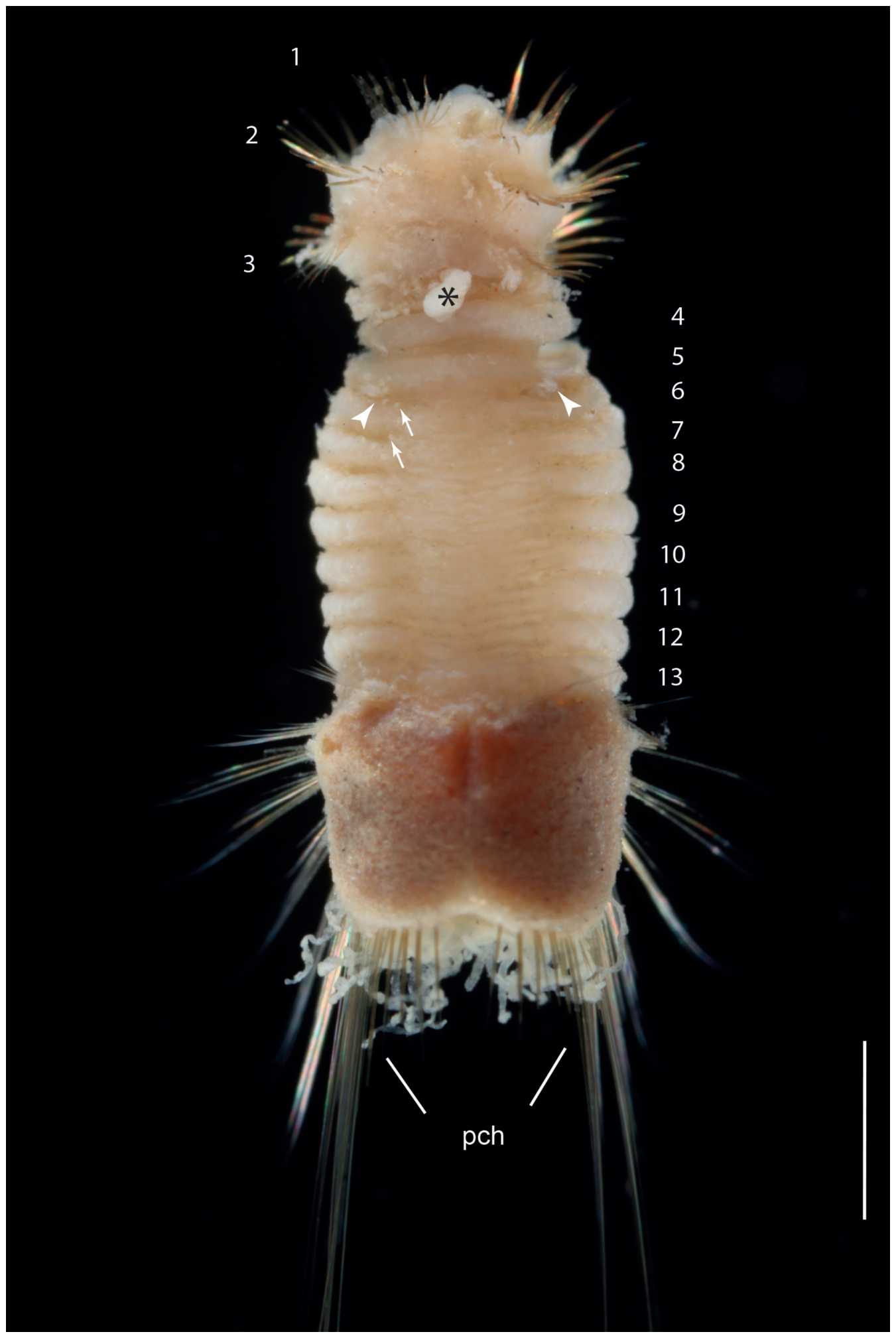

Fig. 1. Mauretanaspis longichaeta gen. et spec. nov., holotype (MNHN-IA-TYPE 2005), ventral view. Abbreviation: $\mathrm{pch}=$ posterior shield chaetae; $*$ = body damaged with oesophagus protruding; numbers $1-13=$ anterior and pre-shield segments; arrowheads = gonopodial lobes; arrows = body papillae. Scale bar: $1 \mathrm{~mm}$. 


\section{Description}

Based on holotype (Figs 1, 2A-C, 3A-C), complete specimen (body slightly contracted but introvert fully everted), complemented by paratype (Fig. 4A-C) where indicated.

Body COLOuR. Pale yellow.

Prostomium. Small hemispherical cupule, pale, semi translucent. Eyes absent.

Peristomium. Surrounding mouth projecting to level of prostomial cupule, about $1.5 \times$ diameter of prostomium. Mouth small, round.

INTROVERT. First three chaetigers each with 15-17 hooks on either side (segment 1: left 9+6 small, right $8+8 ; 2$ : left $9+7$, right $9+8 ; 3$ : left $9+6$, right $8+7$ ); hooks golden, tapering to blunt transparent tip; decreasing gradually in length and diameter from dorsal to ventral in each fascicle. Ventralmost 6-8 hooks small to minute. Hooks equally spaced in fully everted introvert (Figs 1, 2A-C, 3A, 4A). Minute drop-shaped papillae in single rows parallel to segmental folds dorsally in segments $1-3$. Body damaged ventrally on segments 3-4 with oesophagus protruding (Figs 1, 2C, 3A). Gonopodial lobes small, digitiform, protruding ventrolaterally from intersegmental groove between segments 5 and 6 (Figs 1, 4A-B).

Anterior ABDOMEN (PRE-SHIELd REGION). Comprising eight segments. Body papillae minute, round, forming single rows close to intersegmental folds, sometimes obscured by sediment particles (Figs 1, 4B). Most pre-shield segments of holotype with smooth median surface on ventral side, possibly abraded, and few, short, filamentous papillae on lateral sides; in paratype median surface papillated (Figs 1, 4A). Few filamentous papillae among adhering sediment particles on segments anterior to branchial plates.

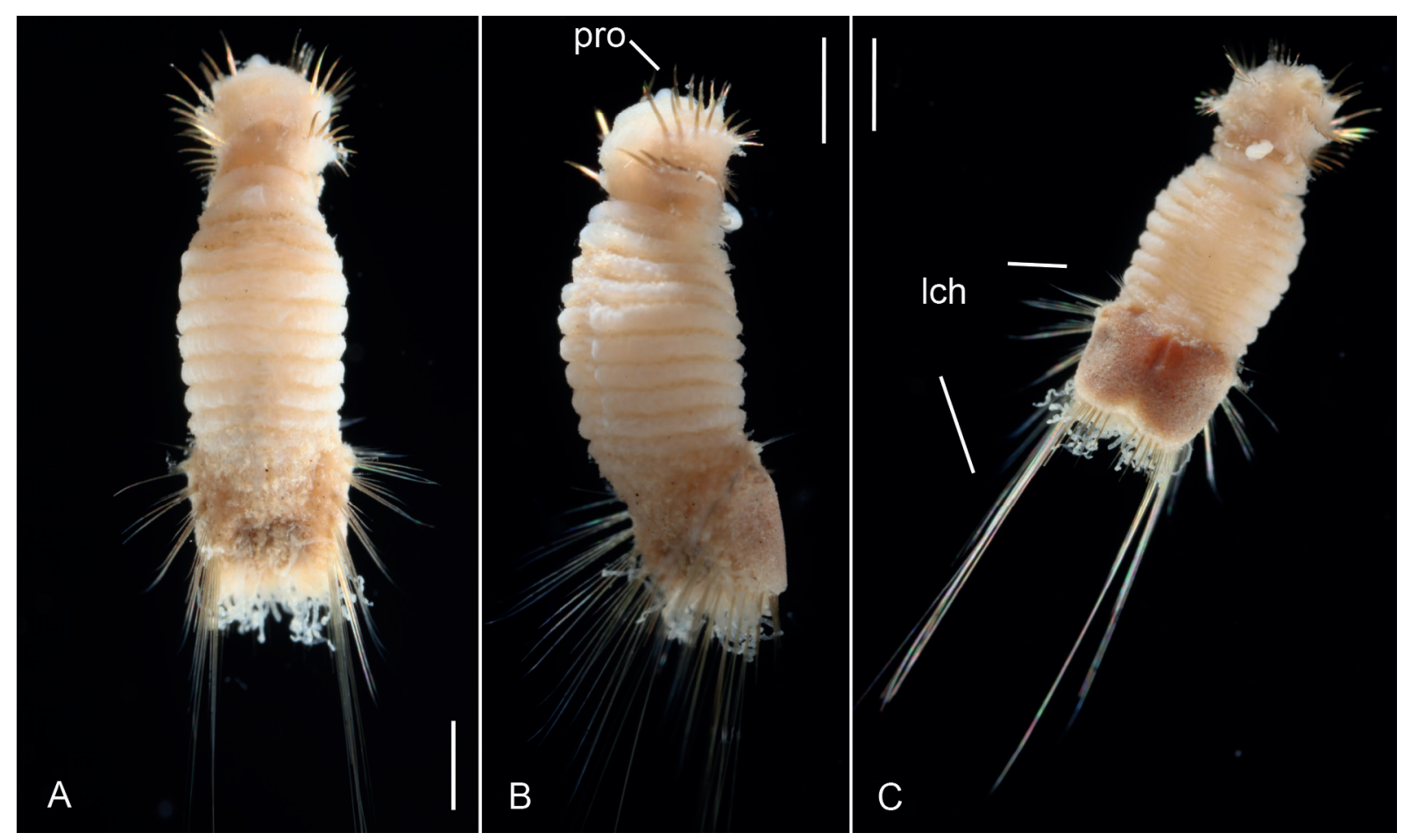

Fig. 2. Mauretanaspis longichaeta gen. et spec. nov., holotype (MNHN-IA-TYPE 2005). A. Dorsal view. B. Lateral view, right side. C. Ventral view showing length of posteriormost lateral chaetae. Abbreviations: $1 \mathrm{ch}=$ lateral chaetae; pro = prostomium. Scale bars: $1 \mathrm{~mm}$. 
FIEGE D. \& BARNICH R., A new genus and species of Sternaspidae from the deep eastern Atlantic

Ventro-CAUdAL Shield. Densely covered by fine, firmly adhering sediment particles. Shield colour light brown, obscured by dense cover of sediment. Colour most intense around anterior end of median suture (sediment abraded in holotype, not abraded in paratype) (Figs 3B, 4A). No structures (ribs, concentric rings) visible due to sediment cover. Anterior margins slightly rounded, anterior depression shallow, covered by sediment; anterior keels faintly visible (Fig. 3B), not exposed. Lateral margins rounded, strongly bent towards dorsal side, not forming free, stiff or pliable margins, but rather merging into integument. Posterior fan and lateral notch not discernible due to sediment cover; shallow median notch (more pronounced in paratype (Fig. 4A, C)). Suture defined in anterior $1 / 3$ of shield, moderately deep with distinct lateral borders (Figs 3B, 4A).

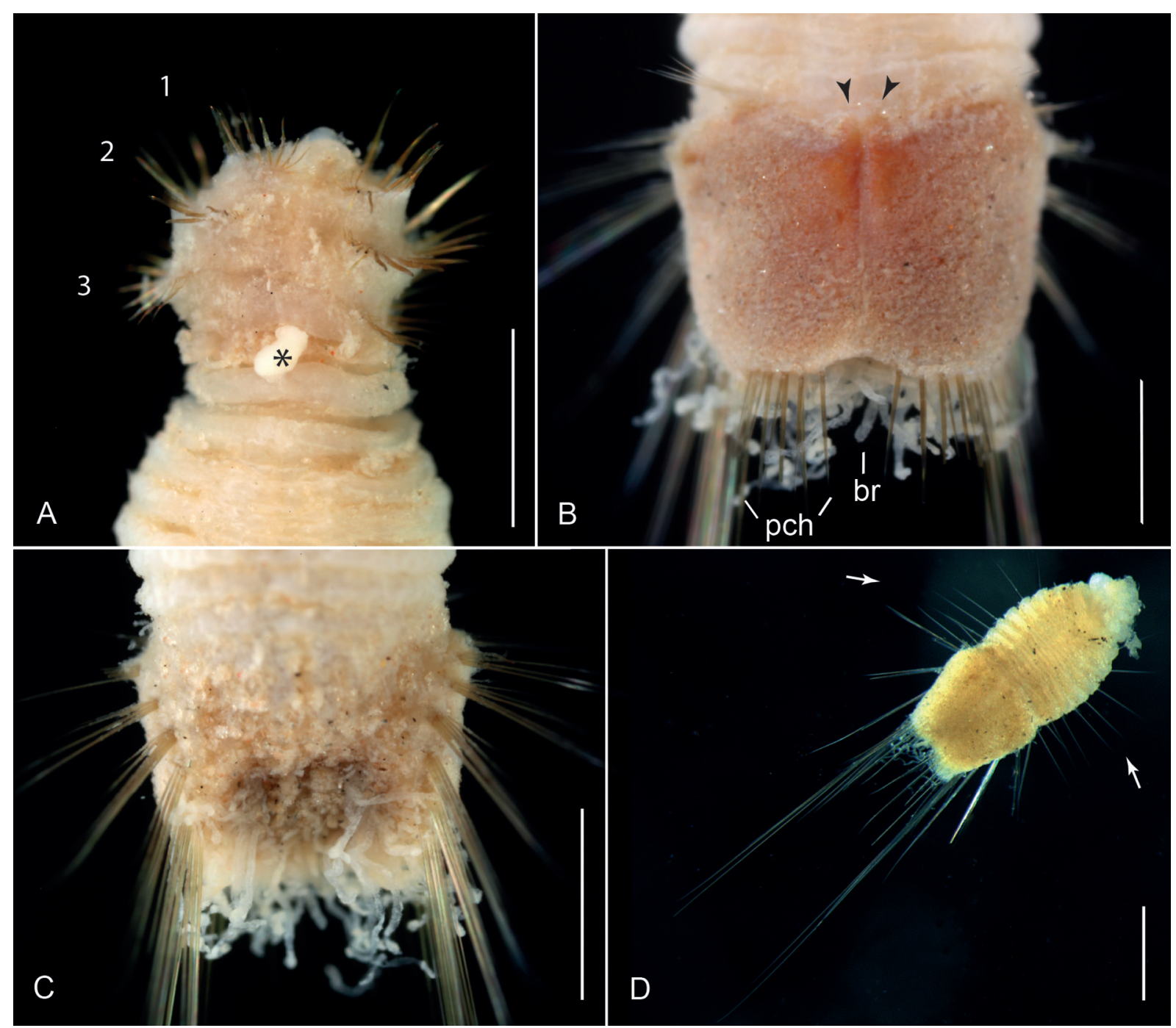

Fig. 3. Mauretanaspis longichaeta gen. et spec. nov. A-C. Holotype (MNHN-IA-TYPE 2005). A. Anterior end (introvert) with tapering hooks, ventral view. B. Ventro-caudal shield, ventral view. C. Posterior end, showing brownish branchial region, dorsal view. D. Juvenile specimen collected off Angola (MNHN-IA-PNT 120) (anterior end damaged, gonopodial lobes not developed), ventral view. Abbreviations: $b r=$ branchial filament; $p c h=$ posterior shield chaetae. Numbers $1-3=$ anterior segments with hooks; $*=$ body damaged with oesophagus protruding; arrowheads $=$ anterior keels of shield; arrows $=$ chaetae of pre-shield segments. Scale bars: $A-C=1 \mathrm{~mm} ; \mathrm{D}=0.5 \mathrm{~mm}$. 


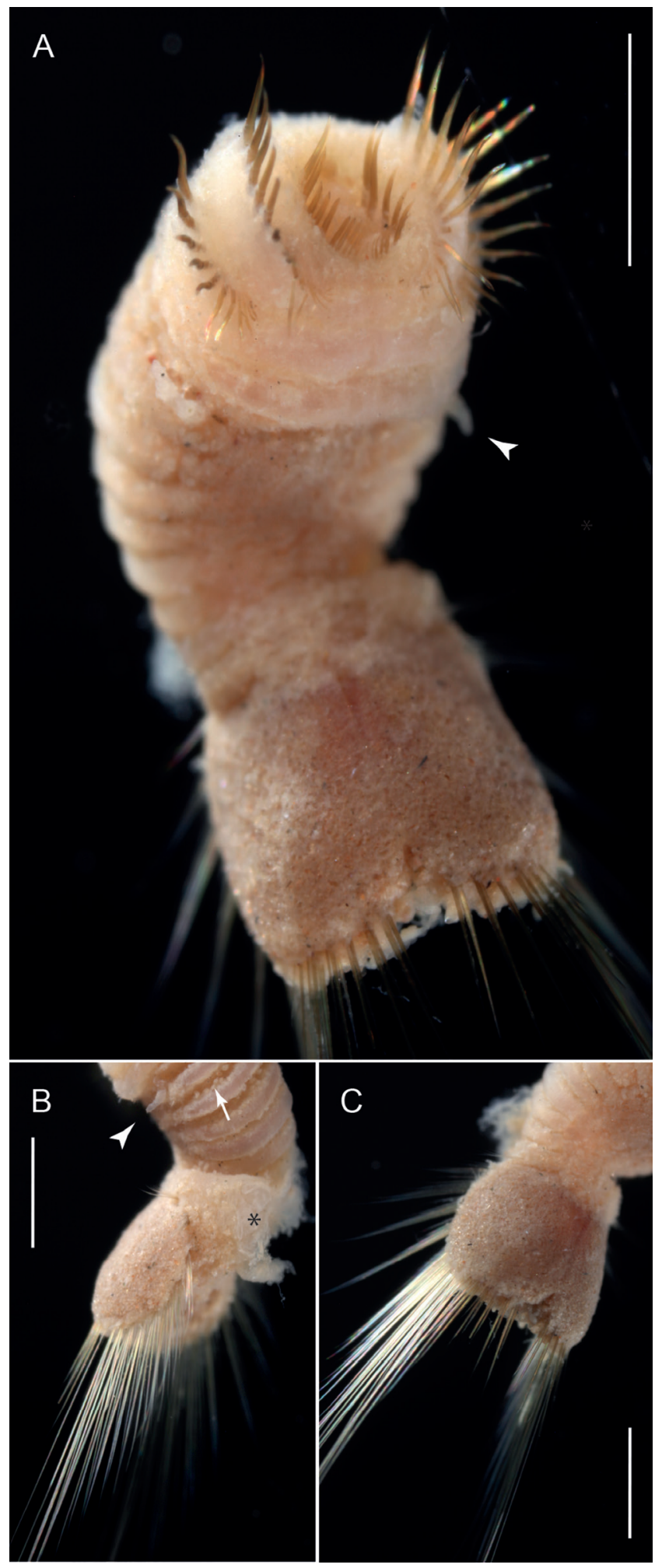

Fig. 4. Mauretanaspis longichaeta gen. et spec. nov., paratype (SMF 27777). A. Entire specimen, ventral view. B. Pre-shield and abdominal region, ventrolateral view. C. Abdominal region, showing arrangement of lateral and posterior shield chaetae, ventral view. Arrowheads = gonopodial lobes; arrow $=$ body papillae; $*$ = body damage on dorsal side. Scale bars: $1 \mathrm{~mm}$. 
FIEGE D. \& BARNICH R., A new genus and species of Sternaspidae from the deep eastern Atlantic

Marginal shield chaetae. Yellow; 20 lateral fascicles, i.e., 9-11 fascicles per side, with 4-6 capillary chaetae each. Chaetae arranged in oblique rows, increasing gradually in length posteriorly within each fascicle and among fascicles (Figs 2C, 3C, 4B-C); chaetae of posteriormost lateral fascicle very long, equalling body length (Figs 2C, 3D). Six pairs of fascicles posterior to shield (i.e., posterior shield chaetae), each with 1-3 (mostly 2) yellow capillaries of varying length and different strength (Figs 3B, 4A, C); lateralmost longest, equalling length of shield. Peg chaetae absent.

BRANCHIAL FILAMENTS. Numerous, increasing in length posteriorly, opaque, coiled to various extent.

Branchial plates. Brownish, forming ovoid to trapezoidal region, densely covered by filaments, filamentous papillae and sediment grains (Fig. 3C).

\section{Distribution}

Northeast to Southeast Atlantic, from off Mauritania to Angola, in deep-sea mud, in depths of 2700 $4400 \mathrm{~m}$.

\section{Remarks}

Mauretanaspis longichaeta gen. et spec. nov. can be distinguished from all other known species of Sternaspidae by the following combination of characters: introvert hooks tapering, tips transparent; pre-shield region with eight segments; ventro-caudal shield densely covered with fine, firmly adhering sediment obscuring shield structures except median suture. Mauretanaspis longichaeta gen. et spec. nov. is the only sternaspid with chaetae in posteriormost lateral fascicles equalling body length. In one specimen collected off Angola (MNCN 16.01/18763), posteriormost lateral chaetae even measure about $4 \times$ the length of the body.

Several specimens from off Angola (SMF 28062, MNCN 16.01/18762, MNCN 16.01/18763, DBUA0002349.01) show black pigment presumably from surrounding sediment included in sediment cover and among sand grains in the branchial region. Black particles are scattered on the shield forming spots of different sizes.

We compared our material to a specimen collected off Northwest Africa in $1320 \mathrm{~m}$ depth and identified as Sternaspis scutata (Ranzani, 1817) by Kirkegaard (2001: 396). The specimen, deposited in the collections of the Natural History Museum of Denmark (NHMD 662048), was not available for study, but pictures of it were kindly made available to us by S. Salazar-Vallejo. Unfortunately, the animal is in very bad condition: anterior hooks tapering to fine tips, number of pre-shield segments and gonopodial lobes not distinguishable, shield completely covered by fine sediment obscuring surface structures, shield without free margins, length of lateral and posterior shield chaetae indeterminable. It remains uncertain whether the sediment can be removed from the shield without damaging it, but with regard to shield characters visible in the pictures available, the specimen appears incorrectly identified as Sternaspis scutata. However, due to its bad condition we cannot identify it any further.

\section{Identification key to Sternaspidae with sediment particles firmly attached to ventro-caudal shield (Caulleryaspis (in part) and Mauretanaspis gen. nov.) (adapted from Salazar-} Vallejo 2017)

1. Shield with anterior depression deep; peg chaetae robust

- Shield with anterior depression shallow; peg chaetae absent 3

2. Shield with anterior margins angular; peg chaetae forming thick, large spines .Caulleryaspis gudmundssoni Sendall \& Salazar-Vallejo, 2013 (N Atlantic, Iceland) 
- Shield with anterior margins rounded; peg chaetae forming thin, small spines ....Caulleryaspis fauchaldi Salazar-Vallejo \& Buzhinskaja 2013 (NE Pacific, Oregon to California)

3. Seven pre-shield segments; chaetae in posteriormost lateral fascicles about length of shield .............................................. Caulleryaspis laevis (Caullery, 1944) (Indo-Pacific, Indonesia)

- Eight pre-shield segments; chaetae in posteriormost lateral fascicles equalling body length ...............Mauretanaspis longichaeta gen. et spec. nov. (NE and SE Atlantic, Mauritania to Angola)

\section{Discussion}

Kobayashi et al. (2018) and Drennan et al. (2019) used molecular techniques to study the taxonomy and systematics of Sternaspidae, but the definition of most sternaspid taxa still relies on morphological characters with the enigmatic ventro-caudal shield being the most prominent. Three genera and respective body patterns were distinguished by Sendall \& Salazar-Vallejo (2013) in their revision of Sternaspis. Their definitions were based on morphological characters of the shield, the introvert hooks and the number of pre-shield abdominal segments. Ventro-caudal shields are described as "stiff" for Sternaspis and Petersenaspis with loose sediment cover easily brushed off, while shields in Caulleryaspis are described as "soft" and easily bent or pliable with sediment firmly adhered. In this case the sediment cover obscures surface structures from observation, i.e., ribs and concentric lines as described for Sternaspis and ribs only for Petersenaspis.

The ventro-caudal shield consists of a framework of fibres and mineralized iron (Bartolomaeus 1992), providing it with a certain degree of firmness. According to Sendall (2006: 19), the distinction beween its stiff- or softness is best tested by trying to bend its margin. In Mauretanaspis longichaeta gen. et spec. nov. the shield margins merge into the integument without forming free margins and thus the shield cannot be tested for its firmness. We consider this character of limited value for a generic distinction, supporting a view that has recently been suggested by Drennan et al. (2019) based on molecular results.

With our definition of Mauretanaspis gen. nov. we agree with Drennan et al. (2019) and consider the adherence of sediment to the ventro-caudal shield, i.e., 'firmly adherent' (not removable) versus 'loosely attached' (easily brushed off), more meaningful for the distinction among genera in combination with other characters as mentioned in Table 2. Following the results of Drennan et al. (2019), Caulleryaspis nuda Salazar-Vallejo \& Buzhinskaja, 2013 is excluded from the identification key, because the combination of the shield characters 'soft, pliable margin' and 'loosely adhered layer of sediment' are not distinctive enough to include this species in the genus Caulleryaspis (see Drennan et al. 2019). Likewise, Caulleryaspis villamari Salazar-Vallejo \& Buzhinskaja, 2013 and C. nana (Zhadan, Tzetlin \& Salazar-Vallejo, 2017) were described with ventro-caudal shield free of sediment particles leaving weakly developed shield structures visible. Therefore, the placement of these two species in Caulleryaspis appears questionable and consequently they are not included in the identification key presented above.

Due to their small size and the lack of indications of sexual maturity, all our specimens of Mauretanaspis longichaeta gen. et spec. nov. might be considered juveniles. However, sexually mature females in specimens of comparable size were reported for Caulleryaspis nana, a species occurring in shallow waters of the South China Sea. A progenetic origin was hypothesized accordingly (Zhadan et al. 2017). A comparison of the chaetation of Mauretanaspis longichaeta gen. et spec. nov. with other sternaspids shows that number and development of chaetae is comparable to larger specimens of other species and that the striking length of the posteriormost lateral chaetae is unique. Typically, juvenile characters for Sternaspidae appear to be a distinctive papillation of the body with longer papillae including the surface of the ventro-caudal shield as shown by Zhadan et al. (2017) for Sternaspis papillosa Zhadan, Tzetlin \& Salazar-Vallejo, 2017. Our animals show only minute body papillae, comparable to those found in presumed adults of other sternaspid species, another argument in favour of establishing the new genus 
FIEGE D. \& BARNICH R., A new genus and species of Sternaspidae from the deep eastern Atlantic

and species. We only consider the smallest specimens examined, i.e., from stations S48-3A (MNHN-IAPNT 120), S48-8A (SMF 28061), S48-14C (MNCN 16.01/18762) and S48-23B (DBUA0002349.01) off Angola, as juveniles because of the absence of gonopodial lobes which we see as an indication that these specimens are indeed not yet sexually mature.

\section{Acknowledgements}

Our sincere thanks go to Tony Savaira at TOTAL E\&P Mauritania (Nouakchott, Mauritania) and Tatiana Gusachenko at TOTAL headquarters (Paris, France) for allowing us to study these highly interesting deep-sea polychaetes from Block C9 off Mauritania. We are deeply indebted to the benthic ecologist team at CREOCEAN (Montpellier, France) for collecting the samples and especially to Romain Le Gall, Sébastien Thorin and Eric Dutrieux for entrusting the marine team at THOMSON ENVIRONMENTAL CONSULTANTS (Guildford, UK) to provide a biodiversity assessment of the sampled area off Mauritania and likewise entrusting Daniel Martín and João Gil (both Blanes, Spain) with the analysis of samples taken off Angola. RB wishes to thank her colleagues at THOMSON for help in extracting and discussing the identity of these fascinating animals. We also thank Danny Eibye-Jacobsen (Copenhagen) and Sergio Salazar-Vallejo (Chetumal) for information and pictures of the specimen identified as Sternaspis scutata by Kirkegaard (2001). Last but not least, we thank João Gil and an anonymous reviewer for their thoughtful comments which helped to improve the manuscript, and Daniel Martín and João Gil for generously providing us with the interesting specimens collected off Angola.

\section{References}

Bartolomaeus T. 1992. On the ultrastructure of the cuticle, the epidermis and the gills of Sternaspis scutata (Annelida). Microfauna Marina 7: 237-252.

Carus J.V. 1863. Vermes. In: Kükenthal W. (ed.) Handbuch der Zoologie. Vol. 2: 422-454. Wilhelm Engelmann, Leipzig.

Caullery M. 1944. Polychètes sédentaires de l'expédition du Siboga. Ariciidae, Spionidae, Chaetopteridae, Chlorhaemidae, Opheliidae, Oweniidae, Sabellariidae, Sternaspidae, Amphictenidae, Ampharetidae, Terebellidae. Siboga-Expeditie 24 (2): 1-204. Brill, Leiden.

Chamberlin R.V. 1919. The Annelida Polychaeta. Memoirs of the Museum of Comparative Zoölogy at Harvard College 48: 1-514.

Drennan R., Wiklund H., Rouse G.W., Georgieva M.N., Wu X., Kobayashi G., Yoshino K. \& Glover A.G. 2019. Taxonomy and phylogeny of mud owls (Annelida: Sternaspidae), including a new synonymy and new records from the Southern Ocean, North East Atlantic Ocean and Pacific Ocean: challenges in morphological delimitation. Marine Biodiversity 49: 2659-2697.

https://doi.org/10.1007/s12526-019-00998-0

Fiege D. 2016. Sternaspidae Carus, 1863. In: Westheide W. \& Purschke G. (eds) Handbook of Zoology Online. Annelida: Polychaetes. De Gruyter, Berlin.

Available from https://db.degruyter.com/view/Zoology/bp_029146-9_24 [accessed 28 Jul. 2020].

Fiege D. 2019. 7.3.1.8. Sternaspidae Carus, 1863. In: Purschke G., Böggemann M. \& Westheide W. (eds) Handbook of Zoology. Annelida: Basal groups and Pleistoannelida, Sedentaria I. Vol. 1: 440-457. De Gruyter, Berlin.

Grube A.E. 1850. Die Familien der Anneliden. Archiv für Naturgeschichte 16: 249-364.

Kirkegaard J.B. 2001. Deep-sea polychaetes from northwest Africa, including the description of a new species of Neopolynoe (Polynoidae). Journal of the Marine Biological Association of the United Kingdom 81: 391-397. https://doi.org/10.1017/S0025315401004003 
Kobayashi G., Mukai R., Alalykina I., Miura T. \& Kojima S. 2018. Phylogeography of benthic invertebrates in deep waters: a case study of Sternaspis cf. williamsae (Annelida: Sternaspidae) from the northwestern Pacific Ocean. Deep Sea Research Part II: Topical Studies in Oceanography 154: 159-166. https://doi.org/10.1016/j.dsr2.2017.12.016

Lamarck J.-B. de. 1818. Les Annelides. (Annelides). Histoire naturelle des Animaux sans Vertèbres, présentant les caractères généraux et particuliers de ces animaux, leur distribution, leurs classes, leurs familles, leurs genres, et la citation des principales espèces qui s'y rapportent; précédée d'une Introduction offrant la Détermination des caractères essentiels de l'Animal, sa distinction du végétal et des autres corps naturels, enfin, l'Exposition des Principes fondamentaux de la Zoologie 5: 1-612. Déterville and Verdière, Paris.

Otto A.G. 1821. Animalium maritimorum, nondum editorum, genera duo. I. Sternaspis thalassemoides. / II. Siphonostoma diplochaitus. Verhandlungen der Kaiserlichen Leopoldinisch-Carolinischen Academie der Naturforscher 2: 619-634.

Ranzani C. 1817. Descrizione di una nova specie del genere Thalassema. Opusculi Scientifici I: 112-116.

Rousset V., Pleijel F., Rouse G.W., Erséus C. \& Siddall M.E. 2007. A molecular phylogeny of annelids. Cladistics 23: 41-63. https://doi.org/10.1111/j.1096-0031.2006.00128.x

Salazar-Vallejo S.I. 2014. Three new polar species of Sternaspis Otto, 1821 (Polychaeta: Sternaspidae). Zootaxa 3861 (4): 333-344. https://doi.org/10.11646/zootaxa.3861.4.3

Salazar-Vallejo S.I. 2017. Six new tropical sternaspid species (Annelida, Sternaspidae) with keys to identify genera and species. Zoological Studies 56 (32): 1-16. https://doi.org/10.6620/ZS.2017.56-32

Salazar-Vallejo S.I. \& Buzhinskaja G.N. 2013. Six new deep-water sternaspid species (Annelida, Sternaspidae) from the Pacific Ocean. ZooKeys 348: 1-27. https://doi.org/10.3897/zookeys.348.5449

Selenka E. 1885. Report on the Gephyrea. Reports on the scientific results of the voyage of H.M.S. Challenger during the years 1873-76. Zoology. Vol. 13. Part 36: 3-25.

Available from https://www.biodiversitylibrary.org/page/1108847 [accessed 27 Jul. 2020].

Sendall K. 2006 Review and Revision of the Genus Sternaspis (Polychaeta: Sternaspidae) using Cladistics on Morphological Characters. MSc Thesis, University of Victoria, Canada.

Available from http://dspace.library.uvic.ca:8080/handle/1828/2189 [accessed 27 Jul. 2020].

Sendall K. \& Salazar-Vallejo S.I. 2013. Revision of Sternaspis Otto, 1821 (Polychaeta, Sternaspidae). ZooKeys 286: 1-74. https://doi.org/10.3897/zookeys.286.4438

Zhadan A.E., Tzetlin A.B. \& Salazar-Vallejo S.I. 2017. Sternaspidae (Annelida, Sedentaria) from Vietnam with description of three new species and clarification of some morphological features. Zootaxa 4226 (1): 75-92. https://doi.org/10.11646/zootaxa.4226.1.3

Manuscript received: 11 March 2020

Manuscript accepted: 3 July 2020

Published on: 10 August 2020

Topic editor: Rudy Jocqué

Desk editor: Eva-Maria Levermann

Printed versions of all papers are also deposited in the libraries of the institutes that are members of the EJT consortium: Muséum national d'histoire naturelle, Paris, France; Meise Botanic Garden, 
FIEGE D. \& BARNICH R., A new genus and species of Sternaspidae from the deep eastern Atlantic

Belgium; Royal Museum for Central Africa, Tervuren, Belgium; Royal Belgian Institute of Natural Sciences, Brussels, Belgium; Natural History Museum of Denmark, Copenhagen, Denmark; Naturalis Biodiversity Center, Leiden, the Netherlands; Museo Nacional de Ciencias Naturales-CSIC, Madrid, Spain; Real Jardín Botánico de Madrid CSIC, Spain; Zoological Research Museum Alexander Koenig, Bonn, Germany; National Museum, Prague, Czech Republic. 